\title{
TINJAUAN HUKUM EKONOMI SYARIAH TERHADAP PENGELOLAAN ZAKAT PRODUKTIF DI LEMBAGA INISIATIF ZAKAT INDONESIA (IZI) KOTA PALU
}

\author{
Yusuf $\mathrm{D}^{1}$, Marzuki ${ }^{2}$, Ahmad Arief ${ }^{3}$ \\ ${ }^{1}$ Mahasiswa ${ }^{2,3}$ Dosen Institut Agama Islam Negeri Palu \\ nasrul@gmail.com
}

\begin{abstract}
The potential for zakat if managed properly will encourage the progress and prosperity of Muslims. In practice, zakat must be given to the right person in accordance with the provisions of the Shari'a and can also be empowered productively so that it becomes a source of funds for the ummah, but generally zakat is mostly managed in a consumptive form and the management process has not been effective and efficient so that sometimes the goal of zakat has not been achieved. . The Indonesian Zakat Initiative (IZI), Central Sulawesi, shows that in its role as the Amil Zakat Institution in the city of Palu, it has tried its best in managing existing zakat. In each of its activities, the Central Sulawesi IZI is always based on regulations made by the government and makes its activities an effort to promote the welfare of the people. In the utilization of zakat funds, it is carried out with two distribution models, namely consumptive use or called charity and also a form of productive empowerment. Even so, it is undeniable that there are still shortcomings, especially in the supervision process.
\end{abstract}

Keywords: Islamic Economic Law; Management Zakat; Mustahiq; Productive Zakat.

\begin{abstract}
Abstrak
Potensi zakat yang ada apabila dikelola dengan baik maka akan mendorong kemajuan dan kemakmuran umat Islam. Pada prakteknya zakat haruslah diberikan kepada orang yang tepat sesuai dengan ketentuan syariat dan juga dapat diberdayakan dengan produktif sehingga menjadi sumber dana umat, namun umumnya zakat lebih banyak dikelola dalam bentuk konsumtif dan proses pengelolaan yang belum efektif dan efisien sehingga terkadang yang menjadi tujuan zakat belum tercapai. Pada lembaga Inisiatif Zakat Indonesia (IZI) Sulawesi Tengah menunjukan dalam perannya sebagai Lembaga Amil Zakat yang ada di kota Palu, sudah mengupayakan yang terbaik dalam pengelolaan zakat yang ada. Dalam setiap aktivitas pengelolaannya IZI Sulawesi Tengah selalu berdasarkan dengan peraturan yang dibuat oleh pemerintah dan menjadikan aktivitasnya sebagai upaya dalam mendorong kesejahteraan umat. Dalam pendayagunaan dana zakat dilakukan dengan dua model pendistribusian yaitu konsumtif atau disebut charity dan juga bentuk pemberdayaan secara produktif. Meskipun demikian, tidak dipungkiri masih adanya kekurangan terlebih pada proses pengawasannya.
\end{abstract}

Kata kunci: Hukum Ekonomi Islam; Manajemen Zakat; Mustahiq; Zakat Produktif. 


\section{A. PENDAHULUAN}

Islam adalah agama yang indah, sempurna, dan universal. Syariatnya meliputi semua aspek kehidupan manusia dan mengatur semua segi sendi kehidupan manusia. Dalam ajaran Islam terdapat suatu konsep keadilan sosial yang ditawarkan oleh agama ini, konsep ini telah banyak memiliki landasan dalam Al-Qur'an dan hadis, yakni konsep zakat, infaq dan sedekah. Ajaran tersebut adalah cara Islam untuk memberikan kesejahteraan sosial kepada pengikutnya, dan cara untuk mensucikan harta kekayaan yang didapatkan.

Terkhusus kewajiban zakat memiliki makna yang sangat fundamental, selain berkaitan erat dengan aspek ketuhanan, zakat juga erat kaitannya dengan aspek sosial, ekonomi dan kemasyarakatan. Zakat memiliki peran sebagai distribusi penghasilan dari golongan mampu kepada golongan yang kurang mampu atau tidak mampu dan pada dasarnya merupakan cara untuk mensucikan harta kekayaan yang didapatkan oleh seseorang. ${ }^{1}$ Zakat adalah ibadah ma'liah ijtima'iyyah yang memiliki posisi yang strategis dan menentukan bagi pembangunan kesejahteraan umat. Zakat tidak hanya berfungsi sebagai suatu ibadah yang bersifat vertikal kepada Allah (habluminallah), namun zakat juga berfungsi sebagai wujud ibadah yang bersifat horizontal (hablumminannas). ${ }^{2}$

Potensi zakat yang ada jika terkelola dengan baik dan amanah, zakat akan mampu meningkatkan kesejahteraan umat serta sebagai institusi pemerataan ekonomi. Selama ini praktik zakat lebih banyak di dominasi oleh zakat konsumtif, oleh karenanya manfaat yang didapatkan tidak berlangsung lama. Pada dasarnya zakat tidak hanya disalurkan secara konsumtif, tetapi idealnya zakat dikelola secara produktif dan dijadikan sumber dana umat. Penggunaan zakat secara konsumtif boleh dilakukan untuk hal-hal yang bersifat darurat, contoh untuk program bencana atau ada mustahiq yang tidak mungkin untuk dibimbing dalam mempunyai usaha mandiri, maka penggunaan kosumtif dapat dilakukan. Pendek katanya adalah jika zakat produktif, mustahiq diberikan modal, sehingga mustahiq dapat mengelola modal yang diberikan

\footnotetext{
${ }^{1}$ Ahmad, Zainal Abidin, Dasar-dasar Ekonomi Islam, (Jakarta: Bulan Bintang, 1979), 88.

${ }^{2}$ Nurul Huda, Zakat Perspektif Mikro-makro Pendekatan Riset, (Jakarta: Kencana, 2015), 5.
} 
sehingga menghasilkan. Praktiknya saat ini lebih banyak mustahiq yang memiliki potensi untuk berusaha namun hanya diberikan zakat konsumtif sehingga kondisi perekonomian mustahiq tidak bisa beranjak pada yang lebih baik. Dana zakat produktif tersebut diharapkan dapat memberikan mustahiq penghasilan tetap melalui usahanya, peningkatan usaha, serta dapat menyisihkan penghasilannya untuk ditabung. ${ }^{3}$

Sebagai landasan dasar dalam mengelola dana zakat yang diterima dari mustahiq. Dalam proses pengelolaan dana zakat pun terdapat banyak sekali regulasi yang menjadi dasar pijakan, tetapi secara umum baik BAZ maupun LAZ mengunakan undang-undang Nomor 23 Tahun 2011. Selanjutnya sebelum menciptakan kesejahteraan bagi masyarakat, tentunya dalam mengelola potensi zakat yang ada dibutuhkan strategi pengelolaan yang baik sesuai dengan standar pengelolaan dan dibutuhkan komposisi manajemen yang merupakan suatu proses bekerja untuk mencapai tujuan-tujuan organisasi. Pelaksanaan pengelolaan mulai dari pengumpulan, perencanaan, pendistriusian dan pengawasan tentunya dibutuhkan kerja lembaga dalam melaksanakan fungsi-fungsi manajeman yakni, perencanaan (planning), pengorganisasian (organizing), pengerakan (actuating), dan pengawasan (controlling).

Lembaga Inisiatif Zakat Indonesia (IZI) kota Palu merupakan salah satu lembaga amil zakat yang resmi dan tercatat dalam pemerintah kementrian agama yang bertugas mengelola zakat secara konsumtif dan juga produktif. Dapat dilihat dari visi misi lembaga tersebut, lembaga IZI memiliki komitmen dalam menjadi lembaga zakat yang profesional dan terpercaya sehingga dapat menginspirasi gerakan kebaikan dan juga pemberdayaan. Tidak hanya itu, dalam mengelola seluruh proses organisasi agar berjalan sesuai dengan regulasi yang berlaku, tata kelola yang baik dan sesuai dengan kaidah syariah. Oleh karena itu, melalui penelitian ini penulis mencoba mengkaji kembali proses pengelolaan dalam tinjaun hukum ekonomi syariah yang nantinya dapat menjadi tolak ukur kesesuaian teori dan praktik yang di terapkan oleh lembaga IZI Kota Palu yang merupakan salah satu lembaga pengelola zakat yang ada di Sulawesi Tengah.

${ }^{3}$ Sartika, Pendayagunaan Zakat Produktif terhadap Pemberdayaan Mustahiq pada LAZ Yayasan Solo Peduli (Surakarta: Jurnal Ekonomi Islam La Riba, 2008), 77. 


\section{B. HASIL DAN PEMBAHASAN}

\section{Program-Program Pendayagunaan Dana Zakat IZI Sulawesi Tengah}

IZI merupakan singkatan dari Inisiatif Zakat Indonesia yakni sebuah lembaga sosial yang bergerak pada penghimpunan, penyaluran dan pemberdayaan dana zakat. Alasan utama lembaga ini hadir adalah untuk membangun lembaga pengelola zakat yang otentik, dengan fokus dalam pengelolaan zakat serta donasi keagamaan lainnya. ${ }^{4}$ Saat ini terdapat beberapa cabang atau perwakilan IZI yang telah dipisahkan dengan lembaga induknya yaitu PKPU diberbagai daerah provinsi yang ada di Indonesia, salah satunya di Sulawesi Tengah tepatnya di Kota Palu.

Pada proses pengelolaan zakat di IZI Sulawesi Tengah terdapat 5 macam program pokok, yaitu IZI to Help, IZI to Success, IZI to Smart, IZI to Iman, dan IZI to Fit. Pada dasarnya ke 5 macam program ini merupakan program turunan dari IZI Pusat yang mengunakan istilah-istilah modern. Orang-orang yang merumuskan dan menginisiasi terhadap istilah-istilah tersebut adalah mereka yang tergabung dalam Bold Of Directur (BOD). BOD didalamnya terdiri dari direktur utama, direktur edukasi dan kemitraan, direktur operasional, dan direktur pendayagunaan.

Istilah-istilah tersebut dirumuskan oleh BOD mencakup dalam penyaluran dana zakat atau penerima manfaat diantaranya bidang sosial, ekonomi, pendididkan, dakwah, dan kesehatan. Istilah di atas yang kemudian menjadi pedoman bagi kantor perwakilan yang ada di daerah provinsi dalam merumuskan program kerja. Berdasarkan data wawancara yang diperoleh bahwa dari ke 5 bentuk pemberdayaan dana zakat masih terdapat bagian-bagian program didalamnya, program tersebut sebagai berikut :

\begin{tabular}{|l|l|}
\hline \multicolumn{1}{|c|}{ Kategori Program } & \multicolumn{1}{|c|}{ Nama Program } \\
\hline IZI to Help & 1. Layanan Mustahiq (LAMUS) \\
& 2. Peduli Bencana \\
& 3. Layanan Jenazah Terpadu (LATAHZAN) \\
& 4. Pemberian Kaki Palsu \\
& 5. Program Qurban \\
& 6. LAMUS Gharimin \\
& 7. Proteksi Keluarga Mustahiq \\
& 8. Kegiatan Ramadhan \\
\hline IZI to Success & 1. Pelatihan Keterampilan Menjahit \\
\hline
\end{tabular}

${ }^{4}$ Admin, https://izi.or.id, diakses pada 21 Maret 2020 


\begin{tabular}{|c|c|}
\hline & $\begin{array}{l}\text { 2. Lapak Berkah } \\
\text { 3. Bina Ternak } \\
\text { 4. Pelatihan Bekam }\end{array}$ \\
\hline IZI to Smart & $\begin{array}{l}\text { 1. Beasiswa Pelajar } \\
\text { 2. Beasiswa Mahasiswa } \\
\text { 3. Beasiswa Khusus }\end{array}$ \\
\hline IZI to Iman & $\begin{array}{l}\text { 1. Da'i Penjuru Negeri } \\
\text { 2. Kampung Bina Muallaf } \\
\text { 3. Peduli Pesantren }\end{array}$ \\
\hline IZI to Fit & $\begin{array}{l}\text { 1. Layanan Kesehatan Keliling } \\
\text { 2. Layanan Pendampingan Orang Sakit (LAPORS) }\end{array}$ \\
\hline
\end{tabular}

Tabel 1: Program pendayagunaan dana zakat di IZI Sulawesi Tengah 2020.

\section{Mekanisme Pengelolaan Zakat Produktif di IZI Sulawesi Tengah}

Pengelolaan zakat secara produktif merupakan model pendayagunaan zakat yang dapat membuat para mustahiq menghasilkan sesuatu secara terus menerus dan dalam jangka yang lama dengan harta yang telah diberikan oleh amil zakat atau lembaga pengelola zakat. Dalam pendayagunaan dana zakat produktif harta yang diberikan kepada mustahiq tidak dihabiskan atau dikonsumsi melainkan harus dikembangkan dan digunakan untuk membantu dan dijadikan sebagai modal usaha agar dapat memenuhi kebutuhan sehari hari dalam jangka waktu yang lama.

Istilah pengelolaan berasal dari kata mengelola yang berarti mengendalikan atau menyelenggarakan. Sedangkan pengelolaan sendiri berarti proses melakukan kegiatan tertentu dengan menggerakan tenaga orang lain. Ruang lingkup dari menajemen pengelolaan adalah mencakup perencanaan, pengumpulan, pendistribusian dan pengawasan.

Pemberian dana zakat dalam lembaga IZI Sulawesi Tengah kepada mustahiq menggunakan dua model yakni model charity atau konsumtif serta pemberdayaan dalam bentuk produktif. Pemberian dana zakat dengan model konsumtif yakni diberikan dalam bentuk bantuan kebutuhan sehari-hari dan kebutuhan yang sifatnya membantu meringankan beban mustahiq pada saat membutuhkan, sedangkan pemberian zakat secara produktif dikhususkan kepada pemberian bantuan dalam bentuk barang, modal usaha dan pemberian pelatihan skill untuk menjadikan mustahiq

${ }^{5}$ Safruddin, Kabid Pendayagunaan Zakat IZI Sulawesi Tengah, wawancara oleh penulis di Kantor IZI Sulawesi Tengah, (30 Juni 2020 
dapat menjadi mandari dan produktif. Setalah melihat secara keseluruhan dari program-program yang ada di IZI Sulawesi Tengah, penulis melihat melihat beberapa program yang sifatnya produktif yang sesuai dengan pokok pembahasan dalam penelitian ini.

Dalam peranya sebagai Lembaga Amil Zakat yang bergerak dalam pengelolaan dana zakat, tentunya IZI memiliki format pengelolaan yang menjadi acuan dasar pengelolaan zakat baik dalam bentuk regulasi yang dikeluarkan oleh pemerintah dan juga mekanisme pengelolaan yang langsung diinstruksikan struktur pusat. Berikut mekanisme pengelolaan yang ada di IZI Sulawesi Tengah:

a. Perencanaan yang dilakukan di IZI Sulawesi Tengah

Tahapan Perencanaan yang dilakukan merupakan tahap awal sebelum sebuah program dilaksanakan. Menurut Didin Hafiduddin perencanaan yang mengikuti syarat ini, dapat disebut dengan perencanaan yang baik, syaratnya yaitu : pertama, adanya keyakinan bahwa apa yang dikerjakan sesuai dengan kebaikan menurut Islam serta Harus bermanfaat untuk orang lain. Kedua, berdasar kepada ilmu pengetahuan terkait apa yang dikerjakan. ${ }^{6}$

Tahap perencanaan yang dilakukan oleh IZI Sulawesi Tengah merupakan tahapan awal sebelum dilakukannya program pendayagunaan zakat. Dalam tahapan ini ada beberapa hal yang dipersiapkan oleh IZI Sulawesi Tengah yakni terkait dengan sumber daya amil dan juga para calon mustahiq atau penerima manfaat.

1) Mempersiapkan sumber daya amil

Dalam pengelolaan zakat mempersipkan sumber daya amil adalah sesuatu yang penting dan harus dilakukan oleh sebuah lembaga amil zakat. Amil zakat adalah orang atau lembaga yang bertugas mengelola jalannya pendayagunaan dana zakat. Oleh karena itu seorang amil haruslah memiliki pengetahuan tentang zakat atau paham tentang mekanisme manajemen sebuah lembaga. Hal ini yang nantinya akan membantu amil dalam menjalankan tugasnya. Pengelolaan yang baik haruslah

${ }^{6}$ Didin Hafiduddin, Hendri Tanjung, Manajemen Syariah dalam Praktik, (Depok: Gema Insani, 2008), 90-91. 
dijalankan oleh orang-orang yang memiliki kapasitas dalam mengorganisasi secara efektif dan efisien.

Memiliki peran sebagai lembaga amil zakat yang tugasnya menjalankan roda pengelolaan zakat. Maka IZI telah mempersiapkan struktur oraganisasi yang terkoordinasi mulai dari pusat sampai ke kantor perwakilan yang ada dibeberapa daerah yang ada di Indonesia. Dalam wawancara yang dilakukan oleh penulis di kantor IZI Sulawesi Tengah dengan membahas terkait bagaimana IZI mempersipakan sumber daya amil kepala perwakilan IZI Sulawesi Tengah, Bapak Sabiin Sy. Lanta menjelaskan bahwa :

Struktur organiasi yang ada di kantor perwakilan merupakan turunan dari pusat dan merupakan sesuatu yang paten dan tidak ada penambahan, untuk strukturnya sendiri terdiri dari kepala perwakilan, bidang edukasi dan kemitraan zakat, bidang keuangan dan administrasi serta bidang pendayagunaan zakat. Terkait jumlah pegawai yang ada di IZI Sulawesi Tengah berjumlah 7 orang pegawai tetap dan 10 orang relawan. Dari masing-masing pegawai bertanggung jawab dan saling berkoordinasi dalam menajalankan tugasnya, untuk tugas relawan adalah membantu dalam hal penyaluran dan nantinya menjadi fasilitator dalam pengawasan program yang ada di IZI Kota Palu. $^{7}$

\begin{tabular}{|c|c|}
\hline Nama Bidang & Jumlah \\
\hline Kepala Perwakilan IZI Sulawesi Tengah & 1 \\
\hline Bagian Keuangan dan Administrasi & 1 \\
\hline Bagian Edukasi dan Kemitraan Zakat & 3 \\
\hline Bagian Pendayagunaan Zakat & 2 \\
\hline Volunteer Tetap & 10 \\
\hline Total & 17 \\
\hline
\end{tabular}

Tabel 2: Sumber daya pegawai IZI Sulawesi Tengah 2020.

Dari hasil wawancara dapat terlihat adanya sturuktur organisasi yang tersusun dari tingkat pusat dan saling terkoordinasi dengan kantor perwakilan yang ada disetiap daerah seluruh Indonesia dalam membantu dan menjalankan tugasnya, setiap struktur

${ }^{7}$ Sabiin Sy. Lanta, wawancara, (30 Juni 2020). 
yang ada di IZI Sulawesi Tengah haruslah memiliki hubungan baik dengan kantor pusat sehingga setiap regulasi yang dibuat oleh pusat dapat dijalankan dengan baik.

2) Perumusan program kerja

Berdasarkan hasil wawancara dengan kepala perwakilan IZI Sulawesi Tengah, Bapak Sabbin Sy. Lanta mengatakan bahwa:

Dalam merencanakan program kerja di IZI Sulawesi Tengah tidak ada devisi khusus yang merencanakan apa saja yang dilakukan dalam pendayagunaan dana zakat, akan tetapi semua pegawai saling bersinergi untuk dalam merencanakan program yang ada. Oleh karena IZI Sulawesi Tengah hanya melaksanakan program pendayagunaan dari pusat saja. ${ }^{8}$

Begitu pula hasil wawancara yang disampaikan oleh Kabid Pendayagunaan zakat, Bapak Syafruddin. S.Sos mengatakan bahwa :

Kantor perwakilan IZI Sulawesi Tengah hanya menjalankan program kerja turunan dari pusat, karena di pusat ada devisi khusus yang membahas dan merencanakan pendayagunaan zakat. Tetapi ada juga beberapa tambahan program ditingkat lokal yang sesuai dengan kebutuhan untuk kantor perwakilan IZI Sulawesi Tengah. ${ }^{9}$

Program kerja yang ada di IZI Sulawesi Tengah adalah program merupakan program kerja yang di Instruksikan dari kantor pusat, tetapi IZI Sulawesi Tengah juga boleh menambahkan program kerja yang sesuai dengan kebutuhan mustahiq yang berada di daerah dan menyesuaikan dengan kelengkapan sarana prasarana di kantor perwakilan itu sendiri.

3) Penentuan mustahiq yang akan menerima program zakat produktif Mustahik adalah orang-orang yang berhak menerima zakat, ketentuan mustahiq telah dijelaskan dalam Q.S At-Taubah (9) : 60 :

Sesungguhnya zakat-zakat itu, hanyalah untuk orang-orang fakir, orang-orang miskin, pengurus-pengurus zakat, para mu'allaf yang dibujuk hatinya, untuk (memerdekakan) budak, orang-orang yang berhutang, untuk jalan Allah dan untuk mereka yang sedang dalam perjalanan, sebagai suatu ketetapan yang diwajibkan Allah, dan Allah Maha mengetahui lagi Maha Bijaksana.

${ }^{8}$ Sabiin Sy. Lanta, wawancara, (30 Juni 2020).

${ }^{9}$ Syafruddin, wawancara,(30 Juni 2020). 
Dalam terjemahan ayat di atas telah dijelaskan tentang orang-orang yang berhak menerima zakat, dalam kajian teori di atas penulis sudah mengahdirkan tentang 8 golongan orang-orang yang berhak menerima zakat berdasarkan Q.S At-Taubah. Berdasarkan hasil wawancara dengan kepala perwakilan IZI Sulawesi Tengah Bapak Sabiin Sy. Lanta mengatakan bahwa :

Pada IZI Kota Palu kriteria mustahiq yang berhak menerima dana zakat dalam pendayagunaan mengikuti perencanaan yang dilakukan di pusat dan juga berdasarkan Q.S At-Taubah. Dalam penyalurannya IZI Sulawesi Tengah melakukan beberapa tahapan dalam merekrut para mustahiq.Tahapan pertama, IZI membuka pendaftaran untuk mustahiq melalui penyabaran informasi melalui media sosial dan media informasi lainya, tahapan kedua, yakni melalui jaringan mitra IZI yang mengusulkan para calon mustahik, namun pada kedua tahapan ini tetap mengikuti proses seleksi berkas. kemudian para tim dari IZI melakukan assesment dengan berkoordinasi dengan pemerintah desa setempat. Selanjutnya setelah para mustahiq dinyatakan lengkap secara berkas dan layak diberikan bantuan, selanjutnya akan dilakukan wawancara terhadap calon mustahiq, wawancara dilakukan dikantor dan di tempat calon mustahiq. ${ }^{10}$

Begitu pula penyataan yang disampaikan oleh Kabid Pendayagunaan Zakat, Bapak Safruddin, S.Sos bahwa :

Sebelum kita menentukan calon penerima manfaat atau mustahiq, kita melakukan survey lapangan dulu, dan juga berkoordinasi dengan pemerintah setempat (RT/KADUS/KADES/LURAH/dll) untuk mendapatkan data-data lengkap terkait calon mustahiq. Dan dalam kriteria mustahiq yang akan diberikan zakat secara produktif IZI adalah orang yang berstatus fakir dan miskin, upaya ini dilakukan untuk membantu para mustahiq agar mandiri. ${ }^{11}$

Dalam tahapan ini dilakukan proses pemilihan mustahiq yang pertama dilakukan adalah menentukan calon mustahiq kemudian melakukan survey dan selanjutnya dilakukan musyawarah untuk menentukan mustahiq tersebut layak atau tidak menerima bantuan dana zakat tersebut dan dinyatakan layak maka lanjut kepada tahapan pendistribusian.

b. Pengumpulan dana zakat

Dana zakat merupakan salah satu yang sangat penting bagi lembaga pengelola zakat dalam upaya mendukung jalannya program dan menjalankan roda operasional

\footnotetext{
${ }^{10}$ Sabiin Sy. Lanta, wawancara, (30 Juni 2020).

${ }^{11}$ Syafruddin, wawancara,(30 Juni 2020).
} 
agar pengelolaan tersebut dapat mencapai maksud dan tujuan dari lembaga pengelola zakat. Pengumpulan zakat bukan hanya menjadi tugas individu, melainkan merupakan tugas negara dalam hal ini BAZNAS sebagai badan pengelola zakat nasional yang berada dibawah naungan pemerintah dan juga lembaga zakat yang membantu BAZNAS serta kesadaran muzakki dalam tanggung jawabnya mengeluarkan zakat.

Dalam operasional pengelolaannya IZI Sulawesi Tengah sebagi lembaga pengelola zakat, IZI tidak hanya mengelola dana zakat, tetapi juga mengelola dana infaq dan shadaqah. Secara keselurusan dana dikelola secara terpisah di arahkan sesuai dengan pos anggaran yang sudah ditentukan, untuk dana zakat dikelola dalam pendayagunaan zakat yang telah ditentukan dalam Al-Qur'an dan telah disepakati oleh ulama. Kemudian, untuk pengelolaan dana infaq dan shadaqah di salurkan kepada program-program yang secara umum dapat menggunakan dana infaq dan shadaqah. Dalam hal ini terdapat beberapa perdebatan mengenai pengunaan dana zakat yang diperuntukan untuk semisal pembangunan masjid, beasiswa pendidikan dan lain-lain. Berdasarkan hasil wawancara yang dilakukan bersama Bapak Sabiin Sy. Lanta, mengatakan bahwa:

IZI Sulawesi Tengah tidak hanya mengelola dana zakat, melainkan juga mengelola dana infaq dan shadaqah. Dari sumber dana ZIS tersebut tentunya berbeda dan peruntukannya sasarannya pun berbeda. Sumber dana zakat yang dikelola di IZI Sulawesi Tengah yakni berasal dari dana zakat yang disetorkan oleh muzakki kepada IZI Sulawesi Tengah. Dana itu kemudian dikelola dan berdayakan kepada program-program pendayagunaan dana zakat. Sementara dana infaq dan shadakah berasal dari dana dari para donatur yang dikelola dan diperuntukan untuk program sosial, keagamaan, kesehatan, dan dakwah diluar dari program yang telah dirumuskan pada program pemberdayaan dana zakat. ${ }^{12}$

Dana zakat umumnya berasal dari muzakki yang telah wajib mengeluarkan zakat, dana selanjutnya disetorkan kepada amil zakat untuk dikelola dan disalurkan kepada 8 ahsnaf penerima zakat. Dana zakat berasal dari harta yang masuk kategori wajib zakat dan sudah memenuhi syarat wajib zakat. Dalam memaksimalkan sosialisasi tentang wajib zakat dan informasi tentang kadar zakat kepada calon muzakki IZI Sulawesi Tengah memanfaatkan media sosial untuk menunjang hal tersebut, alasanya

${ }^{12}$ Sabiin Sy. Lanta, wawancara, (30 Juni 2020). 
karena di zaman yang serba modern ini semua manusia yang hidup bersosial banyak menghabiskan waktu di media sosial, sehingga ini menjadi perhatian dari lembaga zakat untuk membuat inovasi untuk menyebarkan informasi kewajiban berzakat dan menjadikan para calon muzakki tidak perlu bersusah payah untuk datang ke amil zakat untuk menanyakan tentang hal tersebut.

c. Pendistribusian Zakat di IZI Sulawesi Tengah

Pendistribusian zakat adalah salah satu aktivitas dalam manajemen pengelolaan zakat oleh amil zakat. Pendistribusian adalah proses penyaluran dana zakat yang diterima dari muzakki dan disalurkan kepada mustahiq sehingga tercapai tujuan organisasi yang efektif. Sistem pendistribusian zakat dari masa ke masa mengalami perubahan, semula lebih banyak disalurkan untuk kegiatan konsumtif atau charity tetapi belakangan ini banyak pendistribusian dengan model penyaluran dana zakat secara produktif (pemberdayaan).

Salah satu pencapaian dan keberhasilan zakat, yakni pendistribusian zakat secara profesional yang didasarkan kepada landasan yang sehat, sehingga proses distribusi tidak salah sasaran. Dimana orang yang berhak menerima tetapi tidak mendapatkannya malah diberikan kepada yang tidak berhak atau berhak tapi memperoleh jumlah zakat yang mencukupi atau diberikan kepada orang yang kondisi ekonominya lebih baik sementara yang kondisi ekonominya kurang baik justru tidak mendapatkannya. Pola pendistribusian yang dilakukan secara produktif adalah pola penyaluran dana zakat kepada mustahiq yang disertai target merubah keadaan penerima zakat tersebut.

Dalam proses pendayagunaan zakat yang dilakukan oleh IZI Sulawesi Tengah mengunakan dua pola pendistribusian, yakni pendistribusian secara charity (konsumtif) dan juga juga berbentuk pemberdayaan. Namun pada panelitian ini penulis tidak akan membahas lebih jauh mengenai pola pendistrubusian secara charity (konsumtif) karena objek kajian dari penelitian ini adalah pendistribusian zakat secara produktif.

Pada proses pendistribusian erat kaitannya dengan proses perencanaan yang telah dibahas di awal, dimana pada proses perencanaan telah ditentukan para calon 
mustahiq yang akan menerima dana zakat. Menurut hasil wawancara yang didapatkan oleh penulis bahwa :

Tahapan pendistribusian dilakukan secara langsung setelah memenuhi persyaratan yang telah dilengkapi diawal, setelah dilakukan proses administrasi dan wawancara serta survey kelayakan. Pada tahap ini mustahiq juga diberikan edukasi mengenai objek zakat yang diberikan sehingga mampu melakukan pengelolaan nantinya. Ini di harapkan agar barang zakat yang diberikan dapat betul-betul digunakan diberdayakan. Contohnya pada hewan ternak, mustahiq harus paham dulu mengenai pemerliharaan hewan ternak, contoh lainya pada pemberian gerobak berkah penerima manfaat harus sudah pernah melakukan dalam bentuk jual beli. ${ }^{13}$

Pendistribusian di artikan juga sebagai penyaluran dana zakat, penyaluran tentunya dilakukan kepada para penerima zakat, dalam hal ini ialah orang yang masuk 8 ashnaf, hal ini haruslah sesuai peruntukkannya sehingga tujuan zakat akan tepat sasaran dan dapat bermanfaat sesuai kebutuhan sang penerima manfaat. Selain proses pendistribusian secara langsung para penerima zakat juga haruslah diberikan edukasi mengenai objek zakat yang akan diberikan, hal ini dimaksudkan untuk memberikan pengetahuan kepada calon penerima manfaat dalam pengelolaan dana yang diberikan nantinya.

\section{d. Pengawasan zakat}

Fungsi pengawasan sangat penting dalam suatu organisasi. Agar supaya proses pelaksanaan dilakukan sesuai dengan ketentuan dari rencana. Melakukan tindakan perbaikan jika terdapat kekurang dan penyimpangan. Hal ini dilakukan untuk pencapaian tujuan sesuai dengan rencana. Jadi pengawasan dilakukan sebelum proses, saat proses, dan setelah proses. Dengan pengendalian diharapkan juga agar pemanfaatan semua unsur pengelolaan menjadi efektif dan efisien. Dalam pengelolaan zakat, kewajiban yang harus dilakukan setelah tahapan pendistribusian adalah proses pengawasan. Proses pengawasan merupakan control yang wajib dilakukan untuk mengecek terhadap jalannya perencanaan dalam pengelolaan zakat.

Berdasarkan hasil wawancara dengan Kabid Pendayagunaan Zakat, Bapak Syafruddin, S.Sos mengatakan bahwa:

Pada IZI Kota Palu tidak ada bidang khusus untuk tugas pengawasan terhadap para mustahiq dan penerima manfaat, tetapi untuk hal pengawasan dilakukan

\footnotetext{
${ }^{13}$ Syafruddin, wawancara,(30 Juni 2020).
} 
oleh fasilitator yang turun langsung mengawasi dan memberikan bimbingan, contohnya pada program bina ternak, fasilitator mengawasi bagaimana perkembangan ternak yang diberikan dalam pertumbuhannya dan juga memberikan arahan bimbingan berdasarkan pengetahuan dari fasilitator. Seorang fasilitator hanya fokus mengawasi dan melakukan bimbingan pada 1 program saja, tidak boleh melakukan pengawasan pada 2 program sekaligus, hal ini dimaksudkan agar fasilitator fokus pada pengembangan program dan mencapai hasil yang di citakan. ${ }^{14}$

Pengawasan dilakukan untuk mendapatkan hasil pendayagunaan zakat yang sesuai dengan dengan tujuan lembaga zakat, yakni menjadikan mustahiqnya mandiri dan bisa mengembangkan ekonomi keluarga dengan hasil zakat yang diproduktifkan. Namun dalam proses pengawasan terjadi beberapa kendala, baik kepada mustahiq maupun kepada barang zakatnya namun IZI Sulawesi Tengah selalu mempunyai solusi akan permasalahan yang ada.

Harapan dari kami, yakni bagaimana seorang mustahiq itu menjadi muzakki dan yang dulunya menjadi mustahiq nantinya dapat menjadi muzakki. ${ }^{15}$

Karena pengawasan merupakan hal penting dalam pengelolaan zakat produktif, sehingga pengawasan haruslah dilakukan dengan maksimal dan sesuai dengan SOP yang ada. Dalam mendukung proses pengawasan yang dilakukan kepada penerima manfaat IZI Sulawesi Tengah rutin memberikan pembimbingan kepada penerima manfaat untuk selalu memperbaiki ruhiyahnya dengan sang pencipta. Hal ini yang disampaikan oleh Risman S.Pd, selaku penanggung jawab program di IZI Sulawesi Tengah, bahwa :

Dalam melakukan pengawasan, IZI Sulawesi Tengah juga melakukan bimbingan para penerima manfaat untuk selalu memperbaiki hubungannya dengan Allah swt, hal ini dilakukan dan disampaikan oleh kader da'i yang ada di IZI itu sendiri dengan waktu pelaksanaan selama 1 bulan sekali. ${ }^{16}$

e. Faktor pendukung dan penghambat dalam pendayagunaan zakat di IZI Sulawesi Tengah

IZI merupakan lembaga pengelola zakat yang bergerak dalam pengelolaan zakat. Terdapat faktor yang mendukung dan menghambat proses pengelolaan zakat dalam pencapainnya sebagai lembaga zakat. Salah satunya terdapat proses

\footnotetext{
${ }^{14}$ Ibid.,

${ }^{15}$ Syafruddin, wawancara,(30 Juni 2020).

${ }^{16}$ Risman, wawancara, (30 Juli 2020)
} 
pendayagunaan dana zakat secara produktif. Dalam hal ini IZI Sulawesi Tengah telah berupaya maksimal dalam melakukan proses pendayagunaan dana zakat yang ada, namun masih adanya beberapa kendala yang mempengaruhi proses pendayagunaan tersebut. Baik secara proses pengelolaan pada IZI itu sendiri maupun pada saat proses pengawasan yang dilakukan kepada mustahiq penerima manfaat.

IZI Sulawesi Tengah terus mengupayakan yang terbaik dalam proses pendayagunaan zakat tersebut. Berikut beberapa faktor pendukung dan penghambat yang terjadi salam proses pendayagunaan zakat, dengan berdasarkan hasil wawancara yang dilakukan dengan Kabid Pendayagunaan Zakat IZI Sulawesi Tengah. Menurut Bapak Syafruddin, S.Sos mengatakan bahwa :

Dalam proses pendayagunaan dan penyaluran dana zakat, tentunya semua lemabaga zakat memiliki faktor kendala baik yang ada secara administrasi maupun secara langsung di lapangan, tetapi selama ini ketika terjadi permasalahan atau kendala di lapangan, Alhamdulillah, IZI Sulawesi Tengah dapat menyelesaikannya dengan proses kerja sama antar semua bidang yang ada di IZI Sulawesi Tengah. Penyelesaiaan permasalahan ini biasanya dilakukan secara musyarawarah, yakni rapat internal antara bidang-bidang yang sedang mendapakan masalah. Pada proses penghambat yang terjadi dilapangan, biasanya berupa jarak tempuh yang cukup jauh untuk akses ke tempat dimana zakat tersebut disalurkan, dan kendala selanjutnya biasanya terjadi kepada mustahik dan dana zakat tersebut, biasanya ada mustahik yang masih belum cakap dalam mengelola zakat, contohnya zakat hewan ternak, biasanya hewan yang diberikan oleh IZI mati dan tidak peroduktif. Tapi dalam proses penyelesaian masalahnya biasanya IZI memberikan hewan ternak yang baru. ${ }^{17}$

Upaya untuk memperbaiki proses penyaluran dana zakat terus di optimalkan oleh seluruh struktur yang ada di IZI Sulawesi Tangah, sehingga ketika ada masalah dapat dibahas dan diselesaikan dalam sebuah forum musyawarah dan hasil yang didapatkan merupakan keputusan bersama antar sesama pegawai, berikut hasil wawancara yang disampaikan oleh bapak Sabiin. Sy. Lanta selaku kepala perwakilan IZI Sulawesi Tengah.

Dalam proses pengelolaan dana zakat, kami mengacu kepada peranturan undang-undang No. 23 Tahun 2011, dan terus memperbaiki proses pelayanan dan memberi kemudahan bagi para muzakki dalam meyalurkan zakatnya. Dalam pengelolaannya, banyak mengalami masalah, namun kami menyelesaikannya secara musyawarah untuk mencari jalan keluar dari permasalahan tersebut. ${ }^{18}$

\footnotetext{
${ }^{17}$ Syafruddin, wawancara,(30 Juni 2020).

${ }^{18}$ Sabiin Sy. Lanta, wawancara, (30 Juni 2020).
} 
Dari wawancara di atas, penulis menarik kesimpulan bahwa dalam setiap lembaga yang melakukan manajemen pengelolaan, pastinya ada masalah yang terjadi, tidak terlepas dari IZI Sulawesi Tengah Itu sendiri, namun dalam proses penyelesaian masalah yang dilakukan di IZI Sulawesi Tengah menggunakan metode musyawarah dalam mencari jalan keluar dari masalah yang ada.

f. Manfaat dari zakat produktif

Dalam zakat produktif Rasulullah saw telah memberikan contoh sebagaimana yang disebutkan dalam hadis Anas bin Malik yang diriwayatkan oleh Tirmidzi bahwa ketika ada seorang Anshor yang meminta-minta beliau tidak langsung memberikan kepadanya uang tunai, tetapi mengajarkan kepadanya bagaimana berusaha dan bekerja, sehingga dalam waktu singkat orang tersebut menjadi mandiri dan tidak meminta-minta lagi.

Jadi, dengan adanya zakat produktif ini diharapkan bisa membantu para fakir miskin sehingga mereka akan mendapatkan bantuan dari zakat produktif secara terus menerus, serta hasil yang didapatkan akan mengalir terus dan berkembang terus untuk kemashlahatan umat.

Keberadaan pemberdayaan zakat produktif yang dilakukan oleh IZI Sulawesi Tengah sejauh ini sudah membantu beberapa kaum fakir miskin, walaupun belum secara keseluruhan. Hal ini yang di rasakan oleh Ibu Nilawati, beliau sangat terbantu dengan adanya bantuan program lapak berkah yang diberikan oleh IZI Sulawesi Tengah, pekerjaan sehari-hari Ibu Nilawati adalah seorang penjual kue, dengan ada bantuan lapak berkah ini dengan tambahan modal, beliau dapat menambah modalnya dalam menjual kue.

Begitu pula yang disampaikan oleh bapak Asgiarto, beliau salah satu peserta pelatihan bekam yang menjadi program pemberdayaan zakat untuk membekali skill kepada penerima manfaat untuk bisa mengahasilkan usaha yang bernilai ekonomis dari pelatihan tersebut. Belian menyampaikan bahwa keberadaan pelatihan tersebut mendatangkan pemateri yang luar biasa dan juga para peserta dibekali dengan nilainilai dakwah dalam setiap aktivitas bekam. 
Proses penyaluran zakat produktif, tentunya yang menjadi harapan utama adalah bagaimana membantu para kaum fakir miskin untuk bisa menjadi mandiri dan bisa hidup sejahtera tanpa tekanan garis kesengsaraan, karena sesungguhnya agama Islam adalah agama yang mulia yang menjamin umat kebahagiaan dunia dan akhirat dari syariat-syariat yang ada didalamnya.

\section{Tinjauan Hukum Ekonomi Syariah Terhadap Pengelolaan Zakat Produktif di IZI Sulawesi Tengah}

Zakat secara tegas memang dalam hal pendistribusiannya tidak dipisahkan kedalam bentuk konsumtif dan produktif begitu pula tidak satupun dalil naqli ataupun atsar sahabat yang menguraikan tentang bentuk zakat ini. Meskipun demikian, jika dilihat dari roh dan tujuan syariah terkait zakat, maka para ulama kontemporer membolehkan pendistribusian zakat dalam bentuk produktif guna peningkatan taraf hidup perekonomian mustahiq. Sebelum dilakukan pendistribusian, dana zakat harus dikelola dengan benar dan baik sehingga dapat disalurkan kepada orang yang tepat dan sesuai dengan aturan Syariah, sesuai dalam Q.S Al-Hasyr (59) ayat ke-7:

“Apa saja harta rampasan (fa'i) yang diberikan Allah kepada Rasul-Nya (dari harta benda) yang berasal dari penduduk kota-kota, maka adalah untuk Allah, untuk rasul, kaum kerabat, anak-anak yatim, orang-orang miskin dan orangorang yang dalam perjalanan, supaya harta itu jangan beredar di antara orangorang kaya saja diantara kamu. apa yang diberikan Rasul kepadamu, maka terimalah. dan apa yang dilarangnya bagimu, maka tinggalkanlah. dan bertakwalah kepada Allah. Sesungguhnya Allah amat keras hukumannya."19

Mekanisme pengelolaan zakat produktif pada Inisiatif Zakat Indonesia (IZI) Sulawesi Tengah dengan melihat indikator pengelolaan mulai dari proses perencanaan, pengumpulan, pendisribusian dan pengawasan yang menjadi dasar penulis untuk melakukan proses analisis terhadap sistem pengelolaan yang ada dan kemudian mengkajinya mengunakan tinjauan hukum ekonomi syariah sesuai dengan teori yang sudah dijelaskan dalam pembahasan kajian teori. Maka penulis melihat secara umum sistem pengelolaan zakat produkif di tinjau dari prinsip hukum ekonomi syariah sudahlah cukup baik dan sesuai dengan syariat islam, namun masih terdapat

\footnotetext{
${ }^{19}$ Kementrian Agama RI, Al-Qur'an Tajwid dan Terjemahnya, (Bandung: PT. Sygma Examedia Arkanleema, 2010), 546.
} 
kekurangan yang harus disempurnakan dalam proses pengawasan pemberdayaan zakatnya.

Tahap perencanaan dimaksudkan untuk mempersiapkan segala sesuatu yang berkaitan dengan proses pengelolaan mulai mempersiapkan sumber daya amil dan juga mempersiapkan para calon penerima manfaat. Pada masa kontemporer, dalam hal optimalisasi pengumpulan zakat akan lebih baik jika melalui perantara atau biasa disebut dengan intermediary system yang mana yang dimaksud dalam zakat adalah badan amil zakat atau lembaga amil zakat. Agar pengumpulan dana zakat akan lebih professional. Proses untuk mempersiapkan sumber daya pengelola zakat setidaknya dapat terpenuhi syarat antara lain: ${ }^{20}$

1. Amil zakat merupakan seluruh pihak yang sanggup berperan melaksanakan segala urusan penghimpunan, simpanan, mencatat, menjaga, serta menyalurkan dana zakat.

2. Kewajiban yang diemban oleh amil zakat terdapat yang bertabiat pemberian kuasa yang wajib penuhi persyaratan yang diresmikan oleh para ulama fikih, antara lain beragama Islam, pria, dapat dipercaya serta mengenali hukum zakat.

3. Amil zakat sepatutnya memiliki etika keislaman, semacam ramah kepada seluruh pihak, serta senantiasa mendoakan mereka begitu pula terhadap mustahik dan bisa menarangkan kepentingan zakat dalam menghasilkan solidaritas sosial dan mendistribusikan zakat kepada mustahiq.

Demi pengelolaan zakat yang professional, maka instansi pengelola zakat hendaknya menggunakan prinsip good organization govermance, dengan syarat yang harus dipenuhi adalah amanah dan trasparan. Tata kelola yang baik adalah salah satu tolak ukur keberhasilan sebuah lembaga amil zakat. Sejauh yang penulis ketahui bahwa IZI Sulawesi Tengah dalam hal ini sebagai lembaga amil zakat sudah mempersipakan sumber daya amil dalam proses manajemen pengelolaan zakat. Namun penulis melihat beberapa hal yang menjadi kekurangan yakni sumber daya amil yang masih terbilang

${ }^{20}$ M. Arief Mufriani, Akuntansi Manajemen Zakat, (Jakarta : Kencana Prenada Media Group, 2008), 195. 
sedikit dalam instansi tersebut, hal ini penulis pandang cukup untuk untuk struktur lembaga yang sudah penulis cantumkan di bab hasil penelitan. Melihat pengetahuan pengelola zakat yang ada dilembaga tersebut penulis melihat secara keseluruhan berasal latar belakang keilmuan yang berbeda-beda, namun tidak menjadi masalah yang serius karena mengedukasi para amil zakat sudah dilakukan di IZI Sulawesi Tengah.

Tahap perencanaan selanjutnya adalah pemilihan calon penerima manfaat atau mustahiq sudah sesuai dengan ketentuan Al-Quran yang dijelaskan dalam Q.S At-Taubah ayat 60, pada proses penyalurannya di lapangan IZI Sulawesi Tengah lebih memperioritaskan para kaum fakir dan miskin hal ini didasarkan kepada Undangundang No. 23 Tentang pengelolaan zakat. Hal ini dilakukan untuk memperbaiki taraf hidup dari penerimanya. Ini dilakukan IZI karena fakir dan miskin sangatlah derajat keharusannya untuk dibantu diatas dari 7 golongan lainnya. Tetapi IZI tidak menutup ruang untuk mendistribuskan zakat kepada 7 golongan lainya dengan dibuktikan adanya program khusus untuk membantu dengan bentuk program charity.

Berdasarkan hasil data yang diterima oleh penulis tentang para calon penerima manfaat dominan berstatus kurang mampu atau miskin. tentunya penetapan ini setelah mendapatkan data-data dari pemerintah setempat terkait dengan calon penerima manfaat. Latar belakang pekerjaan dari calon penerima manfaat petani dan IRT, dan banyak dari mereka yang masih tinggal dikontrakan.

Fakir dan miskin adalah kelompok yang paling umum untuk bisa dikaitkan dengan kemiskinan dan tingkat kesejahteraan di Indonesia. Posisi fakir dan miskin sebagai asnaf semestinya menjadi penting untuk diketahui dan diperioritaskan. AlQur'an menyebutnya sebagai kelompok pertama dan kedua yang berhak menerima zakat. Ini menunjukan bahwa tujuan utama dari zakat adalah menyelesaikan problem kemiskinan. ${ }^{21}$ Bahkan dalam konteks zakat fitrah, fakir dan miskin itulah yang secara tegas disebutkan Nabi Muhammad saw dalam hadisnya :

Ibnu Abbas berkata, "Rasulullah saw mewajibkan zakat fitrah untuk mensucikan orang yang berpuasa dari kesia-siaan dan kejahatan serta memberi makan orang yang miskin. barang siapa yang menunaikan sebelum sholat Idul Fitri maka

${ }^{21}$ Dede Rodin, Rekonstrukti Konsep Fakir dan Miskin Sebagai Mustahiq Zakat, Ijtihad, Jurnal wacana hukum Islam dan Kemanusiaan, Volume 15, No. 1, 2015. 
zakatnya diterima. Dan barang siapa yang menunaikannya setelah shalat Idul Fitri maka itu adalah shadaqah".22

Selama ini permasalahan yang muncul dalam proses penyaluran zakat kepada fakir miskin adalah ketidakjelasan kriteria dan batasan masing-masing. Secara umum indikator fakir dan miskin adalah ketidakmampuan secara materi dan memenuhi kebutuhannya atau secara indikator kemampuannya mencari nafkah dimana dari hasil usaha tersebut belum bisa memenuhi kebutuhannya. Kesimpulanya adalah fakir merupakan seseorang yang tidak mempunyai harta serta pendapatan yang cukup sementara seseorang dengan kategori miskin yaitu mempunyai pendapatan namun tidak mencukupi kebutuhannya.

Selanjutnya, Pengumpulan dana zakat yang dilakukan di IZI Sulawesi Tengah merupakan dana dari para muzakki yang dikeluarkan dari harta yang telah masuk kategori wajib zakat. Pada proses pengumpulannya dana yang terkumpul masuk di rekening pusat dan ketika akan melaksanakan program kerja setiap kantor IZI Perwakilan harus mengajukan proposal untuk proses pencairan dana zakat tersebut. Pengumpulan dana zakat tersebut di IZI menggunakan rekening terpisah antara rekening infaq. Hal ini dilakukan untuk mencegah bercampurnya dana infak dan zakat. Para muzakki yang melakukan pembayaran zakat selanjutnya bisa melakukan pembayaran melalui transfer dan juga bisa datang langsung ke kantor. Setelah pembayaran dilakukan maka muzakki selanjutnya diberikan bukti pembayaran dan bukti pembayaran kemudian dilaporkan ke pusat.

Proses pengumpulan dilakukan melalui rekning bank dan dibayarkan langsung ke kantor perwakilan yang ada di beberapa daerah, berdasarkan penelusuran penulis kepada media sosial Inisiatif zakat Indonesia (IZI), penulis melihat adanya rekening bank konvensional yang digunakan dalam mengumpukan dana zakat yang ada, hal ini jelas membuat tambahan bunga pada rekining bank tersebut. Ketentuannya adalah dana direkening giro/tabungan/deposito bank konvensional itu dilarang karena transaksi yang terjadi dalam produk giro, tabungan dan deposito adalah utang piutang

\footnotetext{
${ }^{22}$ Sunan Abu Daud, hadis No. 1371.
} 
(pinjaman) dimana nasabah sebagai kreditur dan bank sebagai debitur sesuai dengan peraturan yang berlaku pada praktik perbankan.

Menabung di bank konvensional sekalipun dinamakan simpanan, akan tetapi dalam pandangan fikih akadnya adalah pinjaman (qardh). Pengertian qardh ini sama dengan tabungan, dimana uang tabungan yang disimpan di bank digunakan oleh bank, kemudian bank mengembalikannya kapan dibutuhkan oleh penabung dalam bentuk penarikan uang tabungan. Sebagai mana kaidah fikih menyebutkan "Setiap pinjaman yang memberikan keuntungan bagi pemberi pinjaman adalah riba". ${ }^{23}$ Kebijakan tersebutnya berpotensi menghasilkan harta non halal, karena setiap dana yang mengendap itu utang berbunga yang diharamkan. Namun, hal ini dibolehkan dengan persyaratan yang ketat yaitu jika memiliki maslahat lebih banyak. Penghimpunan dana boleh dilakukan melalui bank konvensional namun dengan persyaratan dibuatkan transfer otomatis ke bank syariah sehingga dana yang masuk tidak mengendap lama pada bank konvensional, Adapun jika terdapat bunga maka diambil jalan tengahnya bahwa bunga tersebut tidak digunakan oleh operasional melainkan akan dijadikan sebagai dana sosial, serta diperbolehkan berzakat melalui bank konvensional karena lebih banyak orang wajib zakat yang menggunakan rekening tersebut sehingga untuk memudahkannya maka dibolehkan agar menghindari keenggenan pembayaran zakat dengan alasan berbeda rekening. ${ }^{24}$ Dalam tulisan ini tidak mengkaji lebih dalam persoalan penghimpunan dana, karena penghimpunan dana dilakukan oleh pusat dan di simpan di rekening pusat.

Selanjutnya pada tahap pendistribusian zakat produktif haruslah mencerminkan sifat kejujuran dan kebenaran, hal ini harus jelas dalam setiap aktivitas yang dilakukan oleh IZI Sulawesi Tengah, karena atas dasar kejujuran dan kebenaran IZI Sulawesi Tengah masih eksis sampai sekarang dan banyak dipercaya dikalangan mitra IZI, banyak lembaga-lembaga sosial maupun lembaga keuangan yang menggandeng IZI Sebagai mitra dalam penyaluran dana sosial dan juga zakatnya.

\footnotetext{
${ }^{23}$ Erwandi Tirmizi, Harta Haram, Muamalat Kontemporer, (Bogor : PT. Berkat Mulia Insani, 2017),403-404.

${ }^{24}$ Oni Sahroni, M. Suharsono, Agus Setiawan, Adi Setiawan. Et al.,eds, Fikih Zakat Kontemporer (Depok : Rajawali Pers, 2019), 252.
} 
Sebagaimana yang kita ketahui, bahwa Allah swt telah menyebutkan delapan kelompok yang wajib menerima zakat. Terkait pembagian zakat kepada delapan kelompok mustahiq, Terdapat ikhtilaf yang dapat disimpulkan sebagai berikut $:^{25}$

1. Dana zakat pada dasarnya haruslah diberikan kepada semua kategori mustahiq apabila zakat yang terkumpul mencukupi untuk itu.

2. Dana zakat didistribusikan kepada seluruh kategori mustahiq dengan bagian yan tidak sama. Namun, masing-masing mendapatkan bagian sesuai dengan kebutuhan mustahiq. Karena pada suatu daerah pasti memiliki perbedaan keadaan.

3. Jika amil atau lembaga zakat memandang maslahah yang lebih besar dapat diperoleh, maka dibolehkan mendistribusikan dana zakat tidak pada seluruh kategori mustahiq, namun hanya sebahagian saja.

4. Menyalurkan kepada kelompok yang paling membutuhkan ialah fakir dan miskin. hal ini disebutkan target utama zakat adalah untuk memenuhi kebutuhan mereka agar tercukupi dan bisa mandiri sehingga pada akhirnya mereka tidak lagi membutuhkan lagi bantuan dana zakat.

Tahapan yang terakhir adalah pengawasan, pada tahap ini sangatlah penting untuk melihat keberhasilan dari zakat produktif yang diberikan, menurut KH Didin Hafiduddin bahwa jika memberikan zakat produktif harus pula melakukan pembinaan dan pendampingan kepada para penerima zakat agar kegiatan usahanya dapat berjalan dengan baik, disamping itu juga harus membina rohani dan intelektual keagaamaannya, agar semakin meningkat kualitas keimanannya dan keislamannya. ${ }^{26}$

Pengawasan yang dilakukan sebagai pendampingan kepada penerima manfaat selama kurang lebih 1 tahun. Selama proses pendampingan mustahiq diberikan edukasi dan pengetahuan tentang Islam yang dilakukan oleh da'i IZI Sulawesi Tengah yang dilakukan dalam 1 bulan sekali dan juga para tim fasilitator melakukan monitoring di tempat penerima manfaat untuk dilihat manfaat perkembangannya. Kemudian, setelah

${ }^{25}$ Oni Sahroni, M. Suharsono, Agus Setiawan, Adi Setiawan. Et al.,eds, Fikih Zakat Kontemporer (Depok : Rajawali Pers, 2019), 272-273.

${ }^{26}$ Muhammad Talqiyuddin, Optimalisasi dan Manfaat Zakat Produktif, Kompasiana.com, https://www.google.com/amp/s/www.kompasiana.com/amp/muhammad-taqiyuddin-alfaruqi/optimalisasidan-manfaat-zakat-produktif-558fe856aa23bd4b17beeada. (12 Agustus 2020) 
proses pendampingan selama setahun, IZI Sulawesi Tengah kemudian memberikan kebebasan kepada mustahiq untuk mengelola sendiri zakat produktif yang diberikan dan tidak lagi melakukan pengawasan. Dalam proses ini, ini yang masih menjadi kekurangan dalam pengawasan. Karena setelah satu tahun, bisa terjadi mustahiq yang tidak lagi menjadikan zakat tersebut produktif.

Pada prakteknya proses penyaluran zakat produktif ini hanya berlangsung selama setahun, setelah setahun produktifitas tersebut tidak lagi menjadi perhatian dari IZI Sulawesi Tengah dalam hal ini melepas sepenuhnya mustahiq tanpa adanya timbal balik yang terjadi. Hal ini tentunya akan menjadikan harta zakat tersebut hanya berputar kepada satu orang saja. Harta zakat harus terus dikembangkan dan diproduktifkan agar dapat menghasilkan serta menjadikan mustahik sebagai muzakki. Hal ini menurut penulis skema dalam penyaluran zakat harusnya mengedepankan pola qardul hasan dengan pola: muzakki membayar zakat kepada Lembaga Amil Zakat, selanjutnya Lembaga Amil tersebut menyalurkan kepada mustahiq untuk dimanfaatkan sebagai sesuatu yang produktif sebagai modal usaha, setalah itu keuntungan yang didapatkan dibagi dengan LAZ kemudian LAZ menyalurkan lagi kepada mustahik selanjutnya.

Menurut M. Arief Mufrani dalam bukunya Akuntansi Manajemen Zakat menjelaskan bahwa ukuran keberhasilan sebuah lembaga pengumpulan zakat adalah lembaga tersebut dapat menjadikan salah satu elemen dari sekularitas sosial yang mencoba mengangkat derajat kesejahteraan seorang mustahiq menjadi muzakki. Jika hanya pola konsumtif yang dikedepankan tampaknya akan sulit tujuan ini bisa tercapai. Selanjutnya modal yang dikembalikan oleh mustahiq kepada lemabaga zakat, tidak berarti bahwa modal tersebut sudah tidak lagi menjadi haknya si mustahiq yang diberikan pinjaman tersebut. Ini artinya bisa saja dana tersebut diproduktifkan kembali dengan memberi balik kepada mustahiq tersebut yang akan dimanfaatkan untuk penambahan modal usahanya lebih lanjut. Dan kalaupun tidak, hasil akumulasi dana 
zakat dari hasil pengembalian modal akan kembali didistribuskan kepada mustahiq lain yang juga berhak. ${ }^{27}$

Dengan begitu ada harapan besar lembaga amil dapat benar-benar menjadi patner bagi mustahiq untuk pengembangan usahanya sampai terlepas dari batas kemustahikkan. Akhirnya, penulis memberikan kesimpulan bahwa dalam pengelolaan zakat produktif yang dilakukan pada IZI Sulawesi Tengah sudah cukup baik, tetapi penulis melihat terjadi kekurangan dalam hal pengawasan yang terjadi setelah satu tahun IZI kemudian memberikan kebebasan tanpa pengawalan terhadap penerima manfaat tersebut.

\section{KESIMPULAN}

Mekanisme pengelolaan mulai dari tahap perencanaan, pengumpulan, pendistribusian dan pengawasan program yang dilakukan Inisiatif Zakat Indonesia (IZI) Sulawesi Tengah sudah cukup baik, tetapi penulis melihat kurangnya proses pengawasan yang dilakukan terhadap penerima manfaat. Pelaksanaan pemberdayaan zakat di IZI Sulawesi Tengah adalah menggunakan pendistribusian konsumtif atau charity dan Produktif. Pendisrtibusian konsumtif atau charity yakni, dana zakat yang di berikan dalam bentuk barang yang dibutuhkan untuk membantu kehidupan seharihari, sedangkan pemberdayaan secara produktif adalah pemberian bantuan yang dapat tumbuh dan berkembang untuk membantu dalam jangka panjang.

Pengelolaan zakat produktif IZI Sulawesi Tengah sudah berjalan cukup baik dengan memperhatikan peraturan yang dibuat oleh pemerintah dan juga berdasarkan syariat Islam. Hanya saja ada beberapa faktor penghambat dalam proses pengelolaan zakat produktif baik terdapat pada amil maupun terdapat pada mustahiq atau penerima manfaat. Keseluruhan prinsip-prinsip syariah yang harus dijalankan dalam setiap aktivitas ekonomi sudahlah di jalankan di IZI Sulawesi Tengah, hal ini lahir sesuai dengan misi dari IZI itu sendiri yakni pengelolaan dan pengorgansasian yang sesuai dengan kaidah syariah. 2008), 166.

${ }^{27}$ M. Arief Mufriani, Akuntansi Manajemen Zakat, (Jakarta : Kencana Prenada Media Group, 


\section{REFERENSI}

Ahmad dan Zainal Abidin, Dasar-dasar Ekonomi Islam, Jakarta: Bulan Bintang, 1979

Admin, https://izi.or.id, diakses pada 21 Maret 2020

Huda. Nurul, Zakat Perspektif Mikro-makro Pendekatan Riset, Jakarta: Kencana, 2015

Hafiduddin. Didin, dan Hendri Tanjung, Manajemen Syariah dalam Praktik, Depok: Gema Insani, 2008

Kementrian Agama RI, Al-Qur'an Tajwid dan Terjemahnya, Bandung: PT. Sygma Examedia Arkanleema, 2010

Mufriani. M. Arief, Akuntansi Manajemen Zakat, Jakarta : Kencana Prenada Media Group, 2008

Rodin. Dede, Rekonstrukti Konsep Fakir dan Miskin Sebagai Mustahiq Zakat, Ijtihad, Jurnal wacana hukum Islam dan Kemanusiaan, Volume 15, No. 1, 2015.

Sahroni. Oni, M. Suharsono, Agus Setiawan, Adi Setiawan. Et al.,eds, Fikih Zakat Kontemporer, Depok : Rajawali Pers, 2019

Sartika, Pendayagunaan Zakat Produktif terhadap Pemberdayaan Mustahiq pada LAZ Yayasan Solo Peduli, Surakarta: Jurnal Ekonomi Islam La Riba, 2008

Talqiyuddin. Muhammad, Optimalisasi dan Manfaat Zakat Produktif, Kompasiana.com, https://www.google.com/amp/s/www.kompasiana.com/amp/muhammadtaqiyuddin-alfaruqi/optimalisasi-dan-manfaat-zakat-produktif558fe856aa23bd4b17beeada. (12 Agustus 2020)

Tirmizi. Erwandi, Harta Haram, Muamalat Kontemporer, Bogor : PT. Berkat Mulia Insani, 2017 